of nephrology, Athens 1981. Thessalonika, Greece: International Society of Nephrology, $1981: 299$.

${ }^{4}$ DeFronzo RA, Humphrey RL, Wright JR, Cooke CR. Acute renal failure in multiple myeloma. Medicine (Baltimore) 1975;54:209-23.

${ }^{5}$ Cosio FG, Pence TV, Shapiro FL, Kjellstrand CM. Severe renal failure in multiple myeloma. Clin Nephrol 1981;15:206-10.

${ }^{6}$ Bear RA, Cole EH, Long A, Johnson M. Treatment of acute renal failure due to myeloma kidney. Can Med Assoc 7 1980;123:750-3.

7 Feest TG, Burge PA, Cohen SL. Successful treatment of myeloma kidney by diuresis and plasmaphoresis. Br Med f 1976; :503-4.

${ }^{8}$ Locatelli F, Pozzi C, Pedrim L, et al. Steroid pulses and plasmaphoresis in treatment of acute renal failure in multiple myeloma. Proc Eur Dial Transplant Assoc 1980;17:690-4.

9 Johnson WJ, Kyle RA, Dahlberg PJ. Dialysis in the treatment of multiple myeloma. Mayo Clin Proc 1980;55:65-72.

${ }^{10}$ Robinson EL, Gowland E, Ward ID, Scarge JH. Radioimmunoassay of free light chains of immunoglobulins in urine. Clin Chem 1982;28: 2254-8.

11 Bryan CW, McIntrie KR. Effect of sustained diuresis on the renal lesions of mice with Bence Jones producing tumors. F Lab Clin Med 1973;83: 409-16.
12 Penny R, Castaldi PA, Whited HM. Inflammation and haemostasis in paraproteinaemias. Br 7 Haematol 1971 ;20:35-44.

${ }^{13}$ Harris J, Alexian R, Hersh E. Immune function in multiple myeloma, impaired responsiveness to keyhole limpet haemocyanin. Can Med Assoc F 1971;104:389-92.

${ }^{14}$ Myers GH, Witten DM. Acute renal failure after excretory urography in multiple myeloma. American fournal of Radiology 1971;113:583-8.

${ }^{15}$ Levi DF, William RC, Lindstrom FD. Immunofluorescent studies of the myeloma kidney with special reference to light chain disease. $A m \mathcal{F} M e d$ 1968;44:922-33.

${ }^{16}$ Preuss HG, Weiss FR, Lammarino RM, Hammock WJ, Murdaugh HV. Effects on rat slice function in vitro of proteins from the urine of patients with myelomatosis and nephrosis. Clinical Science and Molecular Mediwine $1974 ; 46: 283-94$.
cith

$17 \mathrm{McGeogh}$ J, Falconer Smith J, Ledingham J, Ross B. Inhibition of active transport of sodium potassium ATPase by myeloma proteins. Lancet 1978;i:17-8.

${ }^{18}$ Durie BGM, Salmon SE. A clinical staging system for multiple myeloma. Cancer $1975 ; \mathbf{3 6}: 842-54$.

(Accepted 26 fuly 1983)

\title{
Comparison of human versus porcine insulin in treatment of diabetes in children
}

\author{
S A GREENE, M A SMITH, B CARTWRIGHT, J D BAUM
}

\begin{abstract}
The blood glucose control obtained when using semisynthetic monocomponent human insulin (insulin A) was compared with that using standard monocomponent porcine insulin (insulin B) in 14 children in a double blind crossover study. At the start of the study age, duration of diabetes, insulin dose, and daily carbohydrate intake were the same in both groups. After a one month run in period of standard treatment with porcine insulin the children were randomly divided into group 1 (three months of insulin $A$ followed by three months of insulin B) and group 2 (three months of insulin $B$ followed by three months of insulin A). During each treatment period blood glucose control was assessed by clinical symptoms, glycosylated haemoglobin, and home blood glucose monitoring.

Although a significant difference in the period after lunch during 24 hour blood glucose profiles suggested a shorter onset time and faster peak action time of human insulin, no significant difference in the overall diabetic control was seen between the two types of insulin. There was a trend towards improved blood glucose control (irrespective of insulin) as the trial progressed. No
\end{abstract}

\footnotetext{
University Department of Paediatrics, John Radcliffe Hospital, Headington, Oxford OX3 9DU

S A GREENE, MRCP, diabetes research fellow

M A SMITH, BSC, medical laboratory scientific officer

B CARTWRIGHT, BSC, clinical assistant

J D BAUM, MD, FRCP, clinical reader and honorary consultant

Correspondence to: Dr S A Greene.
}

clinical reactions to human insulin occurred, and there was no significant difference in the daily insulin dose between porcine and human insulin.

\section{Introduction}

The final stage in the development of pure insulin is now complete with the introduction of human insulin. A protein with an amino acid sequence identical with that of naturally occurring human insulin can be manufactured either biosynthetically by DNA recombinant techniques ${ }^{1}$ or by chemical modification of porcine insulin. In the latter process the terminal amino acid of the $\beta$ chain of the porcine insulin is substituted by a chemical enzymatic technique replacing alanine with threonine. ${ }^{2}$

We report a clinical trial comparing the effects of chemically modified semisynthetic monocomponent human insulin and monocomponent porcine insulin on blood glucose control in a group of diabetic children.

\section{Patients and methods}

Seventeen children were originally selected for the trial. Informed consent was obtained from the children and their parents and the study protocol approved by the hospital's ethics committee. Three children were unable to complete the trial owing to failure to comply with the data collection. All the children were treated with either human monocomponent Monotard and Actrapid insulin (A) or porcine monocomponent Monotard and Actrapid insulin (B) (Novo). The trial had a double blind, crossover design and began with a one month run in period. During the run in period subjects continued with monocomponent porcine insulin and every effort was made to optimise blood glucose control. The children were then randomly allocated to group 1 (three months of insulin $\mathrm{A}$, changing to three months of insulin $B ; n=8$ ) and group 2 (three months of insulin $B$, changing to three months of insulin $A ; n=6)$. Twelve of the 14 children were treated with a once daily regimen of Actrapid and Monotard, and one child in each group was treated with a twice daily regimen of Monotard and Actrapid insulin. 
At the end of the run in period and at the end of three months with each insulin the subjects were assessed clinically and blood samples taken for estimation of glycosylated haemoglobin. Blood glucose concentration was measured at home at least once daily and a seven point 24 hour profile performed at least twice a month. Blood glucose was measured using Dextrostix and reflectance meters (Glucometer) (Ames). Blood samples were also taken for plasma $C$ peptide estimation. Clinical assessments included documentation of height and weight, insulin dose, reactions to insulin, and hypoglycaemic episodes. Close contact was maintained with all children and their families by telephone together with home visits and routine clinical appointments. Throughout the study the insulin dose was altered as indicated by the assessment of blood glucose control.

All values in the study are expressed as means with standard deviations given in parentheses.

\section{Results}

At the beginning of the study there were no significant differences between the two groups in age, height, weight, duration of diabetes, or initial daily insulin requirements (table). Only one subject showed evidence of endogenous insulin secretion as estimated by random measurement of plasma concentration of $\mathrm{C}$ peptide.

Characteristics of patients on entry to study. Figures are means (SD in parentheses)

\begin{tabular}{|c|c|c|c|}
\hline & & $\begin{array}{c}\text { Group 1 } \\
(n=8)\end{array}$ & $\underset{(\mathrm{n}=6)}{\text { Group } 2}$ \\
\hline $\begin{array}{l}\text { Age (years) [range] } \\
\text { Height }(\mathrm{cm}) \\
\text { Weight }(\mathrm{kg}) \\
\text { Duration of diabetes }\end{array}$ & & $\begin{array}{c}13 \cdot 2(1.8)[10 \cdot 6-16 \cdot 0] \\
155.8(10 \cdot 8) \\
48 \cdot 4(12 \cdot 7)\end{array}$ & $\begin{array}{c}13 \cdot 7(2 \cdot 5)[11 \cdot 0-17 \cdot 7] \\
158 \cdot 5(12 \cdot 6) \\
49 \cdot 3(12 \cdot 7)\end{array}$ \\
\hline (years) [range) & Cnits & $\begin{array}{l}5 \cdot 1(2 \cdot 9)[2 \cdot 5-10 \cdot 1] \\
42 \cdot 0(18 \cdot 4)[24-78]\end{array}$ & $\begin{array}{l}5 \cdot 2(2 \cdot 4)[2 \cdot 7-9 \cdot 1] \\
42 \cdot 3(15 \cdot 7)[30-66]\end{array}$ \\
\hline $\begin{array}{l}\text { Initial daily insulin } \\
\text { dose [range] }\end{array}$ & Units/kg & $0.84(0.16)[0.68-1.19]$ & $0.85(0.15)[0.68-1 \cdot 11]$ \\
\hline
\end{tabular}

The values for glycosylated haemoglobin were $11.9^{\circ}{ }_{0},\left(2.5^{\circ}{ }_{0}\right)$ during treatment with insulin $\mathrm{A}$, and $11.5^{\prime \prime},\left(3.8^{\circ}{ }_{0}\right)$ during treatment with insulin B (difference not significant). Data from blood glucose estimations performed at home were separated into $(a)$ mean fasting blood glucose concentration of all the samples tested during each insulin period, and (b) 24 hour blood glucose profiles compiled from the seven point estimations taken twice monthly. Comparison of the fasting blood glucose concentration during treatment with insulin A $(7.8(4.9) \mathrm{mmol} / 1 ; 141(88) \mathrm{mg} / 100 \mathrm{ml} ; \mathrm{n}=164)$ with that during treatment with insulin $\mathrm{B}(8.3(4.6) \mathrm{mmol} / \mathrm{l} ; 150(83) \mathrm{mg} / 100 \mathrm{ml}$; $\mathrm{n}=146$ ) showed no significant difference (Student's $t$ test). Comparison of the 24 hour blood glucose profiles disclosed a significant difference only in the period after lunch $(A>B ; p-0.01$; pooled $t$ test) (figure).

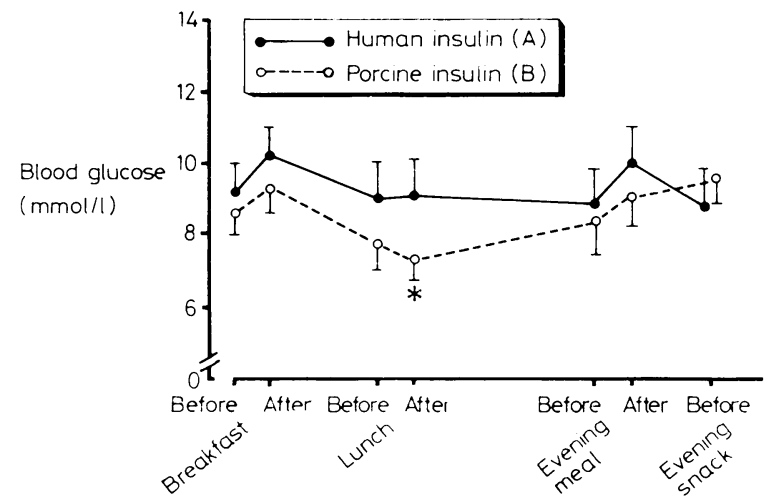

Twenty four hour blood glucose profiles for human and porcine insulin compiled from seven point estimations taken twice monthly. Points are means. Bars are SEM.

${ }^{*} \mathrm{p}<0.02$ (pooled $t$ test).

Conversion: SI to traditional units-Glucose: $1 \mathrm{mmol} / 1 \approx 18 \mathrm{mg}$ / $100 \mathrm{ml}$.
Comparison of fasting blood glucose concentrations throughout the trial irrespective of insulin showed a fall in both groups (group 1: $9 \cdot 9(5 \cdot 3)$ to $8 \cdot 1(5 \cdot 7) \mathrm{mmol} / \mathrm{l}(178(95)$ to $146(103) \mathrm{mg} / 100 \mathrm{ml})$; (group 2: $9 \cdot 0(5 \cdot 1)$ to $7 \cdot 5(2 \cdot 9) \mathrm{mmol} / 1(162(92)$ to $135(52) \mathrm{mg} / 100 \mathrm{ml})$ ). This reached significance in group 1 ( $\mathrm{p}<0.01$; Student's $t$ test).

Total mean daily insulin dose for each insulin rose slightly during the trial (A $47.9(18.8)$ to $48 \cdot 2(17 \cdot 6)$ units; B $44.5(16.4)$ to $45 \cdot 1$ (17.7) units). There was no significant difference in dose between the insulins (Student's $t$ test). No adverse clinical reactions were reported and there were no problems at the site of injection, no skin reactions, and no evidence of lipoatrophy. There were no admissions for ketoacidosis during the trial, and the incidence of hypoglycaemia (only mild, self correcting episodes) was similar with both treatment regimens.

\section{Discussion}

Blood glucose control appeared to improve over the seven months of the trial, irrespective of the order in which the insulins were used. The improvement in blood glucose control presumably related to closer contact with medical staff, regular discussion at home as well as in the hospital clinic, the regular use of home blood glucose measurements, and a possible improvement in the child's understanding of his diabetes and its management. This observation has been noted in studies of diabetes in adults. ${ }^{3}$ The use of a programme of home blood glucose monitoring together with reflectance meters was well tolerated by 14 of the 17 children originally selected, all of whom continued to perform home blood glucose monitoring after the trial.

When comparing the two insulins the only significant difference seen was that of a higher blood glucose concentration after lunch during treatment with the human semisynthetic insulin. Given that the insulin doses were the same for both groups, this suggests a slightly different action time for human insulin. This observation has been noted for biosynthetic human insulin. ${ }^{4}$ Despite this difference, overall control as assessed from mean fasting blood glucose and glycosylated haemoglobin values was the same for both insulins. There were no differences in clinical response to insulin: there was no increase in the incidence of hypoglycaemia and no fall in the daily insulin requirements on changing from porcine to human insulin.

The object of treatment in diabetes is to replace insulin as physiologically as possible; the identical molecular structure of this missing hormone is now available. Theoretical long term benefits have been suggested with its use in the clinical management of diabetes. ${ }^{5}$ Given our finding that blood glucose control with human insulin is similar to that obtained with porcine insulin, our personal view is that human insulin is the treatment of choice for newly diagnosed diabetic children who require many years of treatment with insulin.

We thank Mrs Caroline Owens for technical work and Mrs Maureen Keyworth and Miss Sue Ruddock for preparing the manuscript. SAG is a Novo research fellow.

\section{References}

${ }^{1}$ Chance RE, Kroeff EP, Hoffman JA, Frank BH. Chemical, physical and biological properties of biosynthetic human insulin. Diabetes Care $1981 ; 4: 147-55$.

" Markussen J, Jorgensen K, Kim L, et al. Human monocomponent insulin: chemistry and characteristics of human insulin (Novo). Diabetologia $1981 ; 21: 302$.

${ }^{3}$ Skyler JS, Seigler DE, Reeves ML. A comparison of insulin regimens in insulin dependent diabetes mellitus. Diabetes Care 1982;5, suppl 1:11-8.

' Clark AJL, Knight G, Wiles PG, et al. Biosynthetic human insulin in the treatment of diabetes. Lancet 1982;ii:354-7.

${ }^{5}$ Gerich JE. An appraisal of the role of biosynthetic human insulin in the future treatment of diabetes mellitus. Diabetes Care $1981 ; 4: 262-3$.

(Accepted 18 August 1983) 